\title{
Organizing rural-urban migration of young workers: roles of labor market institutions in postwar Japan
}

\author{
Shinji Sugayama
}

\author{
Correspondence: \\ suga@mail.tohoku-gakuin.ac.jp \\ Tohoku Gakuin University, 1-3-1 \\ Tsuchitoi, Aoba-ku Sendai 980-8511, \\ Japan
}

\begin{abstract}
The Japanese economy's industrial and occupational structure changed drastically during the high growth period. These structural changes were strongly influenced by the flow of junior high school graduates from rural to urban areas. Between 1955 and 1964, six million fifteen-year-old boys and girls entered the labor market immediately on completing compulsory education, with 30-40\% of that total leaving their home prefectures to find jobs nationwide. What made it possible for masses of young workers to find employment on graduation from junior high school? This paper addresses that issue, and sheds light on the critical roles of graduate work placement by public institutions, in particular the nationwide network of Public Employment Security Offices (PESOs) working in cooperation with junior high schools. After looking at the history of graduate work placement from 1925 to 1950, the paper outlines the postwar development of the job placement system and explains the mechanisms used by the employment security administration to organize the rural-urban migration of young workers. Success was, however, achieved at the cost of freedom of occupational choice to which young workers should be entitled by rights. It is argued that an appraisal of the roles of the labor market institutions is no easy matter, since the advantages are intimately interwoven with the disadvantages.
\end{abstract}

Keywords: Rural-urban migration, Labor market institution, Shūdan shūshoku (group employment trip), Graduate work placement, Wartime planned economy, Public employment security office (PESO), Zenkoku Jukyū Chōsei Kaigi (National Conference on the adjustment of graduate supply and demand)

\section{Introduction}

The Japanese economy experienced drastic changes in its industrial and occupational structure during the high growth period. Between 1920 and 1950, there was little change in Japan's industrial structure with half of the working population engaged in agriculture, forestry, and fishery. By 1970, however, the working population of the primary sector where self-employment had been predominant had shrunk to nearly $20 \%$. These structural changes were strongly influenced by the flow of young workers from rural to urban areas. Earlier studies focus in particular on rural-urban migration by high school graduates, i.e. primarily fifteen-year-old junior high school graduates ${ }^{1}$. A considerable number of young people, including those expected to take over the family

(c) The Author(s). 2019 Open Access This article is distributed under the terms of the Creative Commons Attribution 4.0 International License (http://creativecommons.org/licenses/by/4.0/), which permits unrestricted use, distribution, and reproduction in any medium provided you give appropriate credit to the original author(s) and the source, provide a link to the Creative Commons license, and indicate if changes were made. 
business, left rural areas to find jobs as manual workers in cities immediately on completing junior high school. The large supply of cheap, flexible graduates was therefore an important contributory factor to Japan's rapidly expanding economy.

The statistics show that about six million young workers entered the labor market on graduation from junior high school between 1955 and 1964. The annual average stood at 600,000 individuals, and $30-40 \%$ of the total left their home prefectures to find jobs nationwide. The percentage reached well over $50 \%$ for graduates from such prefectures as Akita and Iwate in the Tohoku Region, where most of the working population was engaged in agriculture. Every year in March, as the cherry blossoms came into bloom, a group of fifteen-year-old boys and girls from the Tohoku agricultural areas, together with escorting school teachers and staff from the Public Employment Security Offices (PESOs), boarded special trains for junior high school graduates arranged by the PESOs. They arrived in turn at Ueno Station, where they were entrusted to their employers. These scenes hit the headlines with the impressive caption of "shüdan shīshoku" (group employment trip) and became etched in the Japanese people's minds, creating a new 'collective consciousness' of finding employment on graduation.

The above facts raise some important questions. What made it possible for masses of young people to enter the labor market simultaneously in March, that is, at the end of Japanese school year? How did they get information on job offers in urban areas far from their birthplace when they were still enrolled in junior high school?

These questions can be answered by looking at the roles of graduate work placement by public institutions, in particular the nationwide network of PESOs in cooperation with junior high schools. As will be discussed later, the Japanese government was well aware of the critical importance of high school graduates for the demands of the labor market, and was concerned to match them with jobs for the good of the nation as well as the individual workers. The statistics clearly evidence the rising significance and predominance of this job placement system during the high growth period. The program placed half of junior high school graduates who found employment in 1950, and around $70 \%$ of graduates by the 1960 s. This figure was even higher for the manufacturing sector, where $80 \%$ of junior high school graduates were placed by the system. The Japanese graduate labor market was neither a free market, where job-seekers interact with employers in a competitive environment, nor a labor market driven by personal networks and ties. In this market, it was the government, keen to be involved in the employment process, which played a significant role in matching graduates with jobs. Government intervention in the labor market hence smoothed the transition in a period of drastic change to the industrial and occupational structure.

This paper seeks to explore in detail the historical development of graduate work placement by public institutions. It first looks at how and why this type of work placement originated in the prewar years, before exploring the significant changes that took place during wartime and as a result of democratization under the American occupation. Then, the paper outlines the postwar development of the job placement system, and sheds light on the mechanisms used with considerable success by the employment security administration to organize the rural-urban migration of young workers. The final section appraises the roles of this job placement system viewed from the angle of the young workers themselves. 


\section{Background and emergence of junior work placement ${ }^{2}$}

The origin of graduate placement programs can be traced back to 1925. That year, the Ministry of Home Affairs and the Ministry of Education jointly issued official junior work placement guidelines for local government heads and the chief of the Central Labor Exchange Bureau ${ }^{3}$. The Labor Exchange Law, laying down the foundations for the public labor exchange system in Japan, had been promulgated just 4 years previously.

The guidelines called for labor exchanges to provide a special service for juniors, specifically "those who seek employment immediately on graduation from elementary school", i.e. primarily fourteen-year-old graduates from upper elementary schools. Labor exchanges were instructed to work in cooperation with elementary schools to find "suitable jobs" for individual boys and girls based on "scientific" assessments of their skills. It was this need for cooperation between labor exchanges and elementary schools that was behind the joint signature of the guidelines by the Ministry of Home Affairs and the Ministry of Education.

It is worth noting that these junior job search assistance policies sought to provide graduates with "lifelong employment". Follow-up work was therefore deemed important to ensure continued employment. School teachers and labor exchange staff were expected to make visits to junior workers at work during their first year of employment to monitor their working conditions, hear their complaints, and advise them to be patient wherever possible. This was generally held to be the key aim of follow-up work in Japan.

Junior work placement was originally modeled on practices in use in the United States of America. Yet the American approach was fundamentally different from the Japanese junior placement system. The contemporary American labor exchange system standards, translated into Japanese a year after their publication, stated that the main junior work placement targets were not students currently enrolled in school, but "those who in large numbers have broken off school connections". These young people were inexperienced at contacting employers, and knew little about work or occupations. Employers, for their part, were unwilling to hire under-16s who were protected by child labor legislation. It was therefore felt that junior workers needed a special service. Now jobs for junior workers were generally dead-end jobs, and labor exchange staff were instructed to "assist them when a change of employment seems wise". Follow-up work was important "to guide individuals towards new occupations where necessary or towards further training"4

What accounts for the differences between the United States and Japan? An opinion paper submitted by the Central Committee for Labor Exchanges to the Minister of Home Affairs in 1926 provides an important clue in answer to this question $^{5}$. The paper sought to improve the junior placement system, stating clearly that it was undesirable for boys and girls to seek employment immediately on completing primary education. The argument ran that it was best for a twelve-year-old graduate from lower-elementary school to move on to middle school, and for a fourteen-year-old graduate from upper-elementary school to go on to further education. Yet where family incomes ruled out further schooling, public institutions were expected to provide boys and girls with "lifelong employment" as the second-best option. This was where junior work placement played an important role. 
The abovementioned report's conclusions were based on the idea that an idle period in a young person's life between completing education and settling in an occupation would have negative consequences not only for the individual, but for society and the nation as a whole. Prewar literature on social problems frequently held that such an idle period would lead to juvenile delinquency, and consequently a decline in moral standards and the spread of extreme anti-establishmentarianism. There were two ways to avoid this dangerous void: a) enroll young people in school; and b) settle them in a job.

It was not, however, easy to avoid junior workers drifting around the urban labor market, frequently changing jobs and switching between unemployment and dead-end jobs. What characterized Japanese junior work placement was that the government adopted a policy to solve these problems by imposing restrictions on the job-seeker's freedom of occupational choice. On the launch of the junior placement programs in 1925, the Ministry of Home Affairs' Social Bureau held a five-day training course for those concerned. Lecturer Fusataro Misawa, an engineer from the Central Labor Exchange Bureau, presented the programs' aims as follows:

"Junior workers nowadays are ignorant of the world of work and occupations, and know very little about their own vocational skills. Many junior workers are dismissed before reaching adulthood, and have to change jobs. Lack of a decent system to oversee and protect the employment of junior workers has resulted in a decline in their moral standards, which has led to a significant increase in juvenile delinquency. As unskilled workers, they will always be at risk of losing their jobs"6.

Misawa proposed that junior placement should address this problem by providing junior workers with "lifelong employment" so that they would become "people of character, with a healthy body and soul". Junior workers, however, knew little of the world of work and their own skills and aptitudes. He went on to say:

"To leave them to find employment on their own could lead to an array of problems. The government therefore needs to provide them with suitable jobs, to regulate and oversee their job-seeking activities, and in certain cases, to guide them directly into specific occupations".

Yet there was little room for government intervention in the employment process while the labor exchanges were run independently by local governments. Despite the establishment of the Central and Local Labor Exchange Bureaus as centralizing bodies, it remained hard for a local labor exchange to extend junior work placement beyond its own area of jurisdiction, and the program's geographical scope was actually small. Prewar junior work placement was unable to manage the rural-urban migration of young workers on a nationwide basis.

The statistics show that the number of those placed by the program shot up over a short period of time, reaching 48,000 people in $1936^{7}$. Nonetheless, this number represented just $12 \%$ of new graduates who found employment in that year. In addition, masses of new graduates - 1.6 times the number of those who had found employment - had neither gone on to higher education nor found employment at the time of the survey on October 
1 of graduation year. The percentage of $12 \%$ therefore needs to be discounted to a significant extent.

\section{From "control" to "adjustment": Wartime and postwar reform changes}

\section{The wartime planned economy and control of the graduate labor market}

The Revised Labor Exchange Law, promulgated in 1938, formed a critical turning point for the development of the junior work placement system. The revision, which provided for the nationalization of the labor exchanges, constituted a strategic move towards the wartime mobilization of the workforce nationwide. Specifically, the Japanese government regarded it as most important to control the flow of elementary school graduates, since they were the largest entrants into the labor market every year. The junior work placement instructions, also issued in 1938 jointly by the newly established Ministry of Welfare and the Ministry of Education, stated that the employment of elementary school graduates should "meet and adjust to the needs of the nation" ${ }^{8}$. The purpose of junior work placement shifted from matching new school graduates with suitable jobs to placing them in occupations in accordance with the "the needs of the nation".

To that end, the guidelines supplementing the abovementioned instructions laid down new official procedures for the administration. The administrative hierarchy established by the Revised Labor Exchange Law consisted of three strata: the Ministry of Welfare, the prefectural offices, and labor exchanges in cooperation with elementary schools. Under the newly-created system, schools gauged which students hoped to find employment on graduation, and informed the prefectural offices of the estimated numbers of job applicants by sex and the places they hoped to work by the end of October. The labor exchanges determined which firms were considering hiring new school graduates, and informed the prefectural offices of the estimated numbers of job offers by sex and potential workplaces by the same date. The prefectural offices added up the figures from the schools and labor exchanges and reported them to the Ministry of Welfare by November 10. The necessary information was hence collected and compiled from all over Japan to give the Ministry of Welfare a picture of the general supply and demand conditions for school graduates nationwide. That information was in turn circulated from the top down, such that the prefectural offices would give "instructions" to the labor exchanges in their jurisdiction to help strike a balance between supply and demand nationwide.

A careers guidance system was newly established for the purpose. Under the system, labor exchange staff made their rounds of schools and, together with school teachers, interviewed all the students who hoped to find employment on graduation. At these interviews, the three parties - labor exchange staff, school teacher and student - came to an agreement as to the applicant's suitable job and workplace, information vital to the adjustment of supply and demand. Labor exchange staff reported on the findings in specific papers.

Alongside the enforcement of the Labor Mobilization Plans, the Ministry of Welfare issued new junior work placement guidelines in $1939^{9}$, which ushered in a new era of state control of the graduate labor market. The new guidelines simply stipulated that employers should refer all job offers for school graduates to the government-run labor 
exchanges. Labor exchanges, however, had the right to judge whether the job offers were suitable for school graduates, and to reduce the number of job offers if necessary. In addition, the Ministry of Welfare had the possibility of further reducing the number of job offers to meet the needs of the Plans to Increase Production Capacity.

On the supply side, the Ministry of Welfare determined the "numbers of new graduates each prefectural office shall provide" based on the results of the job applicant survey. Guidelines were in turn circulated from the top down, and the "numbers of new graduates to be provided" were in due course allotted to all elementary schools throughout Japan. Vocational guidance hence became a tool to match new graduates with the government allocation.

The Labor Adjustment Law, promulgated in 1941, was designed to drive home these strict regulations to employers, schools, and job-seeking students. An engineer commenting on the Labor Adjustment Law claimed that the principle of respect of the job-seeker's free will should now be corrected, and that the student's own self-centered demands should be categorically denied. Yet he had to confess that "the working conditions of some establishments assigned to innocent boys and girls send shivers down my spine" ${ }^{10}$. This episode clearly reveals the reality of junior work placement in the wartime period.

\section{Democratization of the employment security administration and the issue of great- sphere placement}

Article 2 of the Employment Security Law promulgated in 1947 stated that, "Anyone can freely choose any available job to the extent that it does not interfere with public welfare". Article 8 went on to stipulate that, "The government shall establish the Public Employment Security Offices as a free service". The Commentary on the Employment Security Law includes an explanation of the aims of the Law presented to the Labor Committee of the House of Representatives:

"The aim of the employment administration is primarily to serve the people ... This Law makes it a principle to respect the freedom of individual activities in accordance with the spirit of the New Constitution, and to approve the employment agencies' activities and private companies' hiring practices to a significant extent, unless attended by evil. Activities attended by evil are, on the other hand, to be sanctioned by much more severe punishments than ever before. This is designed precisely for the protection of workers"11.

One of the underlying concepts of the Employment Security Law can be found in the abovementioned articles and statements: "the freedom to choose an occupation", "the administration [...] to serve the people", "the freedom of individual activities" and "the protection of workers". These principles can be interpreted as the reflection of an administration that prioritizes the individual's fundamental human rights over all others, and that believes in the workings of a labor market where the freedom of job hunting and hiring is highly respected. The government therefore has to be moderate in its regulation of the labor market, save for the removal of evils arising occasionally from market shortcomings. 
However, the Employment Security Law, enacted in the midst of national chaos and devastation just after the end of the war, also included another type of concept that differed from the above principle. That can be found in Article 1:

"The purpose of this Law is to serve a sufficient labor force necessary for manufacturing and other industries and thus to try to secure employment and contribute to the progress of the national economy ..."

To that end, it was stipulated in Article 4 that central government should, "Adjust the demand for supply of the nation's workforce, and establish necessary programs to the best of its ability". These articles can be interpreted as the reflection of an administration that prioritizes the development of the national economy over all others, and undertakes to "adjust the demand for supply of the nation's workforce" if deemed necessary for the nation and industry.

In view of the above arguments, it is not surprising to find that these two different principles underlying the Employment Security Law were occasionally contradictory. The most striking case was the issue of great-sphere placement, i.e. a rural-urban work placement system. It was stipulated in Article 19 that, "The Public Employment Security Offices shall make every effort to place a worker locally in a job unlikely to require a change of permanent residence or place of abode". Applicants could obtain information on the establishments located in their neighborhood with comparative ease, and thereby minimize the risk of being hired for a job with poor working conditions. In the event that actual conditions failed to meet expectations, individuals were free to leave the job and look for another. The article was therefore based on the concept of worker protection.

In 1948, in accordance with the spirit of Article 19, the Ministry of Labor specified the applicable administrative procedures when job offers could not be filled solely by local applicants ${ }^{12}$. These procedures stipulated that the local office could circulate unfilled job offers to other PESOs within the local applicant's commuting distance and, if the vacancies were still unfilled, could contact PESOs beyond the commuting area. However, the Ministry of Labor had divided Japan into five "recruiting blocks", and stipulated that PESOs in different recruiting blocks should not make contact with each other in any event. The circulation of job offers was therefore constrained by the recruiting block boundaries. The policy was designed in particular to prevent textile firm practices of recruiting young female workers from far-flung areas and housing them in dormitories. GHQ reportedly instructed the Japanese government to establish the recruiting blocks with a view to the "democratization of hiring practices"13.

However, the policy had to be revised in the interest of the nation and Japanese economic recovery. As early as 1949, the Ministry of Labor decided to drop the recruiting block system, and introduced new work placement procedures on a nationwide basis ${ }^{14}$. These procedures consisted in the prefectural offices arranging for job offers unfilled by local applicants to be circulated to any available prefectural office in the country, "to meet the need to adjust worker supply for demand in terms of both quality and quantity". The workers concerned were new school graduates and those working in a government-designated "significant industry", i.e. the textile industry, the coal mining industry, and the iron and steel industry. 
Furthermore, in order to provide effective job-search assistance to those workers, the Ministry of Labor and the prefectural offices often held conferences with all the officials concerned as a 'special service'. From the extant literature and interviews with government officials at the time, we can safely conclude that this arrangement had developed into a dual system for junior high school graduates by the 1950s. The system included both Zenkoku Jukyū Chōsei Kaigi (the National Conference on the Adjustment of Graduate Supply and Demand; the National Conference hereafter), and the local conference system called gakusotsu LM (the graduate labor market; the Local Conference hereafter) attended by officials.

Local Conferences were regularly held chiefly in the four largest labor market regions of Tokyo, Chūkyō, Kei-Hanshin and Kita Kyūshū. In the Tokyo region, the Tokyo Metropolitan Office hosted work placement players in the prefectural offices and local PESOs from the neighboring prefectures of Kanagawa, Ibaraki, Gunma, Saitama, and Chiba. Conferences would first inform participants of current regional market conditions before the chair read out the job offers for which local applicants were hard to find or which employers had asked to be circulated outside the local prefecture. The officials from the other prefectures would then make an application for these unfilled offers by a show of hands, and return to their prefectures with them.

The National Conference was held by the Ministry of Labor twice a year for all work placement players throughout Japan. It was particularly important for such a large meeting to soundly manage the information required for the adjustment operations. What served as the basis for this coordination were the surveys of job offers and job applicants conducted by PESOs and junior high schools throughout the country at a given time. Findings were reported on specific forms sent via the prefectural offices to the Ministry of Labor by October 30 . The required information was hence collected and compiled from all over Japan, such that the Ministry of Welfare had a picture of the general supply and demand conditions for new school graduates nationwide and could draw up a list of unfilled job offers to be presented at the first National Conference on November 30. At the Conference, following an information-sharing session, the chair asked for the unfilled job offers to be read out by the relevant officials, and for those from other prefectures to make an application by a show of hands. This arrangement apparently evolved from the 1938 guidelines system, as already discussed.

\section{Postwar development of work placement for new junior high school graduates \\ Work placement in the 1950s}

Postwar Japan made it an overriding priority policy to place graduates from junior high schools newly established by the School System Reform. Statistical records show that this placement program developed quickly within just a few years of its launch. As seen from Table 1, 152,000 junior high school graduates found job placement employment with the help of PESOs in 1950. That constituted 55\% of the total number of graduates employed (job placement ratio 2); over four times higher than the $12 \%$ at which it stood in 1936, as already shown. The job placement system for junior high school graduates rocketed to a predominant position right from the outset. The system's predominance was evidently influenced by the 
Table 1 The results of placement work from 1950 to 1970

\begin{tabular}{|c|c|c|c|c|c|c|c|c|}
\hline \multirow[t]{2}{*}{ Year } & & $\begin{array}{l}\text { No. of } \\
\text { job offers }\end{array}$ & \multirow[t]{2}{*}{$\begin{array}{l}\text { No. of } \\
\text { those employed }\end{array}$} & \multirow{2}{*}{$\begin{array}{l}\text { Ratio of job } \\
\text { offers per } \\
\text { applicant } \\
\text { (B/A: times) }\end{array}$} & \multirow{2}{*}{$\begin{array}{l}\text { Ratio of new } \\
\text { graduates } \\
\text { employed } \\
\text { per job } \\
\text { (C/A: \%) }\end{array}$} & \multirow{2}{*}{$\begin{array}{l}\text { Ration fo } \\
\text { filled } \\
\text { vacancies } \\
\text { (C/B: \%) }\end{array}$} & \multirow{2}{*}{$\begin{array}{l}\text { Ratio of } \\
\text { job } \\
\text { placement } \\
1^{\text {a }} \\
(\%)\end{array}$} & \multirow{2}{*}{$\begin{array}{l}\text { Ratio of } \\
\text { job } \\
\text { placement } \\
2^{b} \\
(\%)\end{array}$} \\
\hline & (A: persons) & (B: persons) & & & & & & \\
\hline 1950 & 337,005 & 193,600 & 152,347 & 0.6 & $45 \%$ & $79 \%$ & $16 \%$ & $55 \%$ \\
\hline 1951 & 398,136 & 323,686 & 256,071 & 0.8 & $64 \%$ & $79 \%$ & $25 \%$ & $68 \%$ \\
\hline 1952 & 415,158 & 386,569 & 254,679 & 0.9 & $61 \%$ & $66 \%$ & $27 \%$ & $62 \%$ \\
\hline 1953 & 385,161 & 408,736 & 271,319 & 1.1 & $70 \%$ & $66 \%$ & $28 \%$ & $58 \%$ \\
\hline 1954 & 353,165 & 427,472 & 265,132 & 1.2 & $75 \%$ & $62 \%$ & $33 \%$ & $65 \%$ \\
\hline 1955 & 389,643 & 426,863 & 293,518 & 1.1 & $75 \%$ & $69 \%$ & $34 \%$ & $62 \%$ \\
\hline 1956 & 517,419 & 509,634 & 375,458 & 1.0 & $73 \%$ & $74 \%$ & $39 \%$ & $64 \%$ \\
\hline 1957 & 575,579 & 680,617 & 442,100 & 1.2 & $77 \%$ & $65 \%$ & $43 \%$ & $65 \%$ \\
\hline 1958 & 547,971 & 668,015 & 405,848 & 1.2 & $74 \%$ & $61 \%$ & $44 \%$ & $65 \%$ \\
\hline 1959 & 555,853 & 668,301 & 424,402 & 1.2 & $76 \%$ & $64 \%$ & $45 \%$ & $65 \%$ \\
\hline 1960 & 488,124 & 949,231 & 414,852 & 1.9 & $85 \%$ & $44 \%$ & $52 \%$ & $70 \%$ \\
\hline 1961 & 388,521 & $1,060,035$ & 332,647 & 2.7 & $86 \%$ & $31 \%$ & $58 \%$ & $74 \%$ \\
\hline 1962 & 478,531 & $1,399,070$ & 414,013 & 2.9 & $87 \%$ & $30 \%$ & $53 \%$ & $70 \%$ \\
\hline 1963 & 532,328 & $1,395,682$ & 459,048 & 2.6 & $86 \%$ & $33 \%$ & $51 \%$ & $67 \%$ \\
\hline 1964 & 478,148 & $1,713,809$ & 432,815 & 3.6 & $91 \%$ & $25 \%$ & $53 \%$ & $68 \%$ \\
\hline 1965 & 448,119 & $1,668,473$ & 412,935 & 3.7 & $92 \%$ & $25 \%$ & $54 \%$ & $71 \%$ \\
\hline 1966 & 360,886 & $1,032,816$ & 328,093 & 2.9 & $91 \%$ & $32 \%$ & $50 \%$ & $69 \%$ \\
\hline 1967 & 315,624 & $1,088,201$ & 290,412 & 3.4 & $92 \%$ & $27 \%$ & $52 \%$ & $70 \%$ \\
\hline 1968 & 281,184 & $1,233,084$ & 259,305 & 4.4 & $92 \%$ & $21 \%$ & $53 \%$ & $72 \%$ \\
\hline 1969 & 245,743 & $1,178,502$ & 227,501 & 4.8 & $93 \%$ & $19 \%$ & $54 \%$ & $75 \%$ \\
\hline 1970 & 198,678 & $1,143,505$ & 196,934 & 5.8 & $99 \%$ & $17 \%$ & $55 \%$ & $77 \%$ \\
\hline
\end{tabular}

Notes: ${ }^{a}$ ratio of job placement $1=$ column (C) / total number of new graduates but those who proceeded to higher education

$\mathrm{b}$ ratio of job placement $2=$ column $(\mathrm{C}) /$ total number of new graduates employed in the secondary and the tertiary sector

Sources: Rōdōshō, Rōdō Shijō Nenpō (yearbook on Japanese labor market), each year: Monbushō, Gakkō

Kihon Chōsa (basic survey on schools), each year

"legacy" of wartime control, which legally enforced the use of government-run labor exchanges for graduate recruitment.

Nevertheless, those who found employment immediately after graduation were still in the minority. Job placement ratio 1 was just $16 \%$ in 1950, with the total number of graduates minus those who went on to higher education taken as the dividend. A large number of the graduates who neither went on to higher education nor found employment hoped to get a job if one were available. Yet in actual fact, only half of those who applied for job openings found employment with PESO assistance. The chief reason for this was, of course, job scarcity. The ratio of job offers per applicant stood at just 0.6 that year. In addition, the ratio of filled vacancies stood at less than $80 \%$ despite market conditions being most advantageous to employers (Table 1). This implies that more than a few job offers accepted by PESOs involved relatively poor working conditions.

However, the number of job offers leapt up to 324,000 the following year driven by the special procurement boom triggered by the Korean War, and continued its upsurge throughout the 1950s. Accordingly, the number of job applicants also rose considerably over the decade. As a result, job placement ratio 1 increased sharply from 16\% in 1950 
to $46 \%$ in 1959 . Graduate jobs in the manufacturing industry grew steadily over the period to attain $70 \%$ of total employment in 1959 . Whereas job placement ratio 2 hovered around $65 \%$ on average in the 1950s, the figure was 10\% higher for those employed in the manufacturing sector. The placement program accounted for three-quarters of new graduates hired as factory workers at the start of the new economic boom period. It is safe to say that the employment administration successfully steered a large flow of young workers from rural to urban areas.

However, the PESOs were so successful at placing a huge mass of job applicants in rural areas that the graduate labor market was rather slack, despite a sharp increase in job offers due to the economic boom. After topping 1.0 in 1953, the ratio of job offers per applicant stagnated at a low level of 1.0 to 1.2 throughout the rest of the 1950s. The ratio of new graduates employed per job applicant also stagnated at around $75 \%$ in the late 1950s.

Furthermore, whereas the above figures present the final results of the placement programs on June 30 of graduation year, Table 2 shows the findings of the surveys of job offers and job applicants on October 30, 1 year before graduation. Table 2 clearly reveals a serious shortage of jobs facing the employment administration before the first National Conference was held. The ratio of job offers per applicant stood at just 0.7 to 0.8 between 1957 and 1959, with a reportedly much lower level in preceding years.

The most important goal for the employment administration in the 1950s was therefore to "secure enough job openings for new graduates". To that end, the Ministry of Labor encouraged the prefectural office staff assembled at the first National Conference to assertively and extensively develop new job offers through the Local Conference system, and to make the most of the guidance system to advise job-seeking students ${ }^{15}$.

How did the prefectural office staff follow these instructions? What did the PESOs actually do? Lack of data makes it very difficult to answer these questions, yet some literature reports that the Kagoshima prefectural office put together a supply and demand adjustment plan after the first National Conference was held in November $1955^{16}$. Table 3 sums up this adjustment plan for those set to graduate from junior high school in the Kagoshima prefecture in March 1956. With respect to future male graduates, the number of job applicants accepted by PESOs as of December 10, 1955 was 3672 people in total, with 1245 individuals hoping to find employment in their home prefecture and 2427 in other prefectures. Yet the number of job offers stood at just 1930 people in total, while job offers from local employers amounted to 1582, which was 337 more

Table 2 The results of surveys on job applicants and job offers as of October 30, one year before graduation

\begin{tabular}{lllll}
\hline $\begin{array}{l}\text { Year of } \\
\text { graduation }\end{array}$ & $\begin{array}{l}\text { No. of job } \\
\text { applicants } \\
\text { (A: thousand persons) }\end{array}$ & $\begin{array}{l}\text { No. of job } \\
\text { offers } \\
\text { (B: thousand persons) }\end{array}$ & $\begin{array}{l}\text { Ratio of job offers } \\
\text { per applicant } \\
\text { (B/A: times) }\end{array}$ & $\begin{array}{l}\text { Ratio of job offers per applicant } \\
\text { on June 30 of graduation year } \\
\text { (times) }\end{array}$ \\
\hline 1957 & 487.9 & 318.6 & 0.7 & 1.2 \\
1958 & 471.9 & 364.0 & 0.8 & 1.2 \\
1959 & 487.4 & 382.8 & 0.8 & 1.2 \\
1960 & 439.5 & 699.3 & 1.6 & 1.9 \\
1961 & 325.4 & 859.1 & 2.6 & 2.7 \\
\hline
\end{tabular}

Sources: Koyō Mondai Kenkyūkai, Shokugyō Antei Kōhō (bulletin for the Employment Security Bureau), February 1957, February 1958, January 1960, January 1961: Rōdōshō, Rōdō Shijō Nenpō (yearbook on Japanese labor market), each year 
Table 3 The plan for adjustment of supply and demand of those scheduled to graduate from junior high schools on March 1956 (the Kagoshima prefecture)

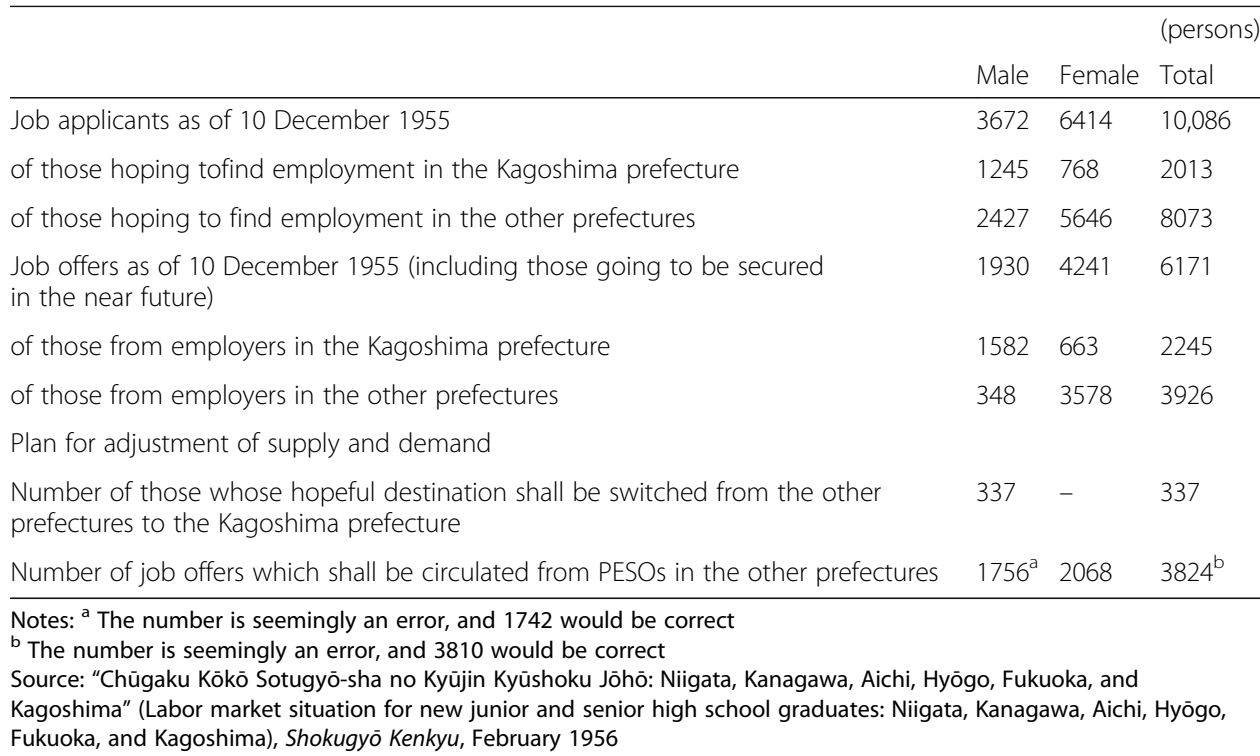

than the applicants hoping to find employment in their home prefecture. There were 348 job offers from employers in the other prefectures, accounting for a mere $14 \%$ of the applicants hoping to find employment in other prefectures.

The Kagoshima prefectural office adopted policies to address this serious supply-and-demand gap. Those policies can be summarized as follows:

(1). The employment administration shall give vocational guidance in cooperation with junior high schools, and have 337 job-seeking students switch their would-be destinations from other prefectures to their home prefecture.

(2). The employment administration shall develop and accept new job offers for 1756 people $^{17}$ from employers in the other prefectures.

In other words, the prefectural office set forth target figures for the administrative adjustment activities so that the ratio of job offers per applicant would be exactly 1.0, not only for those hoping to work in their home prefecture, but also for those hoping to work in other prefectures. To reach this target, the prefectural office required the jurisdiction's PESOs to assertively and extensively develop new job offers through the Local Conferences, held specifically in Aichi and Osaka where the overwhelming majority of job applicants hoped to get jobs.

Furthermore, PESOs were ordered to take affirmative vocational guidance steps to adjust supply to graduate demand. This "guidance" focused on such important matters as switching the would-be destination and ascertaining a suitable occupation. For that purpose, PESO staff had to make their rounds of junior high schools, and interview all job-seeking students repeatedly. They were, it seems, liable to take a high-handed approach under the pressure of the target figures. There is no denying that this administrative guidance could actually have undermined the principle of freedom of occupational choice. 
As shown in Table 1, the ratio of job offers per applicant finally topped 1.0 as a national average in 1956. It seems highly probable that this performance was strongly driven by such abovementioned arrangements devised by government officials to address a serious job shortage.

\section{The labor shortage economy and "Strong Adjustment System"}

The 1960s saw a drastic change in labor market conditions. Table 1 shows that job offers leapt up from 668,000 in 1959 to 949,000 in 1960, and continued to rise sharply up to a peak of $1,714,000$ in 1964. Accordingly, the ratio of job offers per applicant tripled from 1.2 to 3.6 between 1959 and 1964. The ratio of filled vacancies, meanwhile, dropped sharply from $64 \%$ to $24 \%$. Competition among firms for new graduates therefore reached a peak. The Public Employment Security Bureau Newsletter reported on different employers' approaches to new graduates as follows:

"A most popular approach is to invite the families of new graduates to recreational meetings to set up contacts, and get access to their acquaintances. Such kinds of meetings tend to be held very frequently.

One company may send employees back home for a while, and have them approach their friends, acquaintances, and junior fellows. Another company may send a letter as a tactic. The competition is endless! Yet another may raise the hiring bonus, and another may pay the hiring bonus to the person concerned in advance ${ }^{18}$.

The spread of approaches seeking to make direct contact with new graduates and their families would have undermined the job placement system in which PESOs played a major role in cooperation with affiliated junior high schools. The Ministry of Labor consequently issued a historic junior work placement guideline in 1960 to regulate employers' hiring activities ${ }^{19}$. The guideline was revised somewhat the following year and again in 1964. The aim of the 1964 revision was simply to place strong constraints on the hiring of new junior high school graduates ${ }^{20}$. Employers were strongly advised not to use employment agencies to hire graduates, and not to hire graduates independently from outside commuting areas. In addition, recruitment through personal connections was strictly restricted, authorized only in such cases as recruitment of an employer's relatives or close friends. This move restricted the widespread practice of hiring employees' relatives and acquaintances in large Japanese factories. Even hiring through newspapers, magazine advertising, and other publicity devices was prohibited in $1967^{21}$. And companies looking to hire large numbers of employees had no other choice but to submit a job-offer application card to the PESOs.

On receiving job offers for new graduates, PESOs gave off-the-record advice to employers, where deemed necessary. They not only checked the compliance of working conditions such as wages and working hours with the Labor Standards Law, but also checked whether the number of job offers was inflated. In-depth questions were put to employers seeking to recruit workers from outside local applicants' commuting areas to establish whether they had good reason to do so. In 1961, the Ministry of Labor ordered the prefectural offices to conduct preliminary surveys on job offers and job 
applicants. The Public Employment Security Bureau Newsletter explains their aims as follows:

"In our opinion, PESOs can do a good job by giving advice to employers based on scientific nationwide data.

We say, for example, 'In Niigata prefecture, there are approximately four times as many job offers as job applicants. How about hiring from Yamagata prefecture? The ratio is still 2.0 there.'

Most employers will then understand, except those in special circumstances whose recent hiring accomplishments have to be taken into consideration. Such advice would be advantageous to both the administration and employers."22

Also in 1961, the Ministry of Labor launched reforms of the methods used to adjust graduate supply to demand nationwide, and the annual schedule of placement programs was moved forward some 2 months so that the National Conferences could be held three to four times a year. The aim of this new arrangement was to reduce the disparities in ratios of job offers per applicant across prefectures, and set a single target rate. The Ministry of Labor therefore set a target number of job offers for each prefectural office to bring back from the National Conference. In this newly created system, if there was an influx of job offers into a certain prefecture over and above the target number, the surplus offers were transferred to other prefectures where the ratio of job offers per applicant was below the national average. Basically, the administrative authorities spontaneously circulated job offers without the employers' consent wherever they felt it necessary.

The statistics clearly evidence the outcomes of this "strong adjustment system". Table 1 shows that job placement 1 and job placement 2 ratios increased by around $5 \%$ in the 1960s. The ratio of new graduates employed per job applicant, meanwhile, rose from $75 \%$ in the late 1950s to over $90 \%$ in 1964.

Surprisingly, the number of placements per applicant dropped considerably in the early 1960s, despite a sharp rise in the number of job offers ${ }^{23}$. Transition to a labor shortage economy did not necessarily broaden occupational horizons for young workers, but rather strengthened the labor market institutions. It can safely be concluded that it was not the "invisible hand" of the market, but the wheels of the "institutions" that smoothed the transition in the period of industrial and occupational structural upheaval, thus giving birth to contemporary Japanese society.

\section{An appraisal of the job placement system}

This section appraises the roles of the job placement system for new junior high school graduates in postwar Japan, viewed mainly from the standpoints of the young workers themselves ${ }^{24}$. To that end, particular attention needs to be paid to the dynamics of the "institutions" whose aims and roles varied with fluctuations in the labor market's ratio of supply to demand. The Reform of the School System sent masses of fifteen-year-old graduates out into the world at the same time on completing their compulsory education. It created a totally new situation for Japan, since exits from primary education 
had been staggered at different ages before, i.e. lower-level elementary school, upper-level elementary school and different kinds of educational facilities for working youths. It was therefore a serious concern for newly-established junior high schools to be able to send their graduates safe and sound into the world of work. However, economic recovery from wartime devastation was very slow, and an influx of labor due to such factors as returnees from overseas territories and demobilized soldiers meant that job-seekers were everywhere, overflowing from urban labor markets in particular. Despite the fact that the Japanese economy started to boom following the outbreak of the Korean War, the labor market situation continued to be rather slack and depressed for job-seekers throughout the 1950s.

In this environment, the employment security administration made it a work placement goal to "secure enough job openings for new graduates", and developed new job offers assertively and extensively drawing on the nationwide network of PESOs, i.e. the national and the local conference system discussed earlier. Schools working in cooperation with PESOs gave vocational guidance to job-seeking students based on their education and labor market demand, thus helping to adjust supply to demand nationwide. The employment security administration hence succeeded in managing the rural-urban migration of young workers, and the fruits of this system took concrete shape in a social phenomenon that marked a page in postwar Japanese history, i.e. "shüdan shushoku". It is of note that administration officials used to call it the "planned transportation" of graduates.

Despite the term's inhumane overtones, government officials in charge were expected to take a considerate, sympathetic approach to fifteen-year-old boys and girls starting out in the world of work a long way from home. In an interview with the author of this paper, a former official described how this planned transportation program worked in Miyagi prefecture:

"I led a party of students by train from Miyagi prefecture to Ueno station, and handed them over to their employers. But I didn't return home immediately. Instead, I stayed on a week or so in official lodgings in Tokyo ... Yes, sometimes I would receive a call from PESO staff in Tokyo, saying, 'The boy who came here a few days ago says he wants to go home. Could you pop in to see him?'

In such a case, it was not helpful for the boy if a staff member in charge of follow-up work, in Adachi district say (a district with small factories and shops in Tokyo), spoke to the boy in a Tokyo accent. But it could work if a person from the countryside went to talk to him in a provincial accent. I used to say, 'Be patient a while', and the like. ${ }^{25 "}$

As seen from the above statement, PESO staff were required to provide follow-up to junior workers placed in the district in their jurisdiction to help them adjust smoothly to their new environment and stay put in the first job in which they were employed. The former official explained the aims of this work as follows: 
"Officials saw follow-up work as most important to prevent junior workers from changing jobs. After placing a junior worker, I would occasionally pay a visit to him/ her at work, saying 'Hello, how are you getting along? Is there anything wrong?' This work lasted at least six months starting in April. I also conducted a survey of this follow-up work, which was part of the job. I therefore came to know who had quit and who was hoping to leave his/her job.

In those days, it was regarded as a good thing to stay put and bad to change jobs. 'Perseverance will win in the end' was the officials' occupational guidance philosophy ${ }^{26 " .}$

Although most graduate work placement officials were confident about their accomplishments, the press tended to focus on the dark side of "shüdan shüshoku". They presented the public with a stereotype of sad boys and girls working as cheap labor in small factories and shops far from home. Disappointed and frustrated, most of them eventually left their first job. Criticism was often directed at the employment security administration in this case. In December 1966, the Asahi Shimbun, one of the most popular newspapers in Japan, reported on the findings of the company's independent follow-up survey on junior high school graduates who had found employment outside their home prefectures ${ }^{27}$. The front page bore the following subhead printed in large type:

"What is going on with the boys and girls who have found employment outside their home prefectures? The retention ratio is just $36.5 \%$. Poor assistance from the administration has been brought to light."

Pages 5 and 6 were covered with sad stories of junior workers entitled, "Four years of struggling with all their might": Without assistance from the administration on leaving their first job, some drifted around the urban labor market frequently changing jobs, while others had got caught up in big city iniquity, taking to petty crime and the like.

This criticism, however, misses the mark. One month after the above report appeared, Tokyo University's Education Department published in-depth research on the influx of young male workers into Kanagawa prefecture mainly from rural areas. Taking statistically significant data, Ikuo Amano investigated in detail the occupational careers of young workers in the industrial area, and concluded as follows:

"It is by no means an unhealthy phenomenon for the influx of young workers into Kanagawa prefecture to change jobs. Changing jobs actually gives young workers the opportunity to adjust expectations to reality and find their path to a stable working life." $^{28}$

More interestingly, this research provided the ratio of job-switchers per total number of workers by employment route taken. Although the job-switch ratio for workers recruited from the joint efforts of junior high schools and PESOs was very low at $8 \%$, 
job-switchers hired via family and friends stood at $40 \%$, while those recruited from newspapers and advertising came to $57 \%$. The same trend was also found by a survey of male junior high school graduates, which reported the ratio of job-switchers, i.e. those who changed jobs within 6 months of graduation, at $6 \%$ for those hired via PESOs, $4 \%$ for those via schools, $11 \%$ for those through personal connections, and $47 \%$ for those from newspapers, advertising and so on. ${ }^{29}$

The above statistics clearly point to the fact that jobs with which job-seeking students were matched by public institutions were more advantageous than those filled by personal connections and free labor market workings ${ }^{30}$. The advantage was all the greater in the late 1940s and 1950s, when labor market conditions were very harsh for job-seekers. Hiroshi Ishida's analysis based on a comprehensive 1953 survey of junior high school graduates in Kanagawa prefecture reveals that companies hiring new graduates via personal connections were much smaller in size and paid worse than those recruiting via PESOs and schools. Furthermore, Ishida finds that where personal connections were useful only to certain individuals, work placement via these public institutions was open to people from all social strata ${ }^{31}$. We cannot overestimate the role of the institutional placement system, which assertively and extensively developed new job offers for job-seekers and successfully organized rural-urban migration to smooth the transition from school to work for young people in an economy under pressure of a large labor supply.

However, "Where there is much light, the shadow is deep." The success of this job placement system was actually achieved at the cost of freedom of occupational choice to which young workers should be entitled by rights. From the point of view of individuals who found employment through work placement, occupational choice was nothing more than joining the company whose job offer was judged "suitable" for them based on the vocational guidance given by schoolteachers in cooperation with PESO staff. Students knew nothing at all about how information on job offers was collected from across Japan, filtered through the administrative procedure's many steps and ultimately presented to them. Furthermore, as suggested in an analysis of Kagoshima prefecture's 1958 adjustment plan, a student's suitable occupation was not always chosen scientifically, and even the aspired destination could be switched if deemed necessary from the point of view of labor market demand.

When viewed from the standpoint of the young workers themselves, therefore, an appraisal of the roles of the labor market institutions is no easy matter, with pros intricately entangled with cons. Yet in my opinion, though hard to make out at first glance, there was a substantive shift in this delicate balance between the system's advantages and disadvantages in the 1960s, when the Japanese economy morphed into a labor shortage economy. The ratio of job offers per applicant leapt up in 1960 and continued to surge throughout the 1960s. The work placement goal "to secure enough job openings for new graduates" was finally met 100\%. The employment security administration did not, however, take a rest from its work to match job-seeking students with "suitable" jobs and adjust demand to supply nationwide. Instead, the administration made the most of the market situation disadvantageous to employers to take affirmative steps to regulate the free play of employers and adopted the "strong adjustment system".

In the final analysis, companies looking to hire large numbers of graduates had no other choice but to submit a job-offer application card to the PESOs. Furthermore, they were required to submit an "Employee Recruitment Plan", amended by the work 
placement guideline in 1964 with a newly created column to enter the retention ratios for graduates recruited in the last 5 years ${ }^{32}$. The entries in this column were apparently seen as important reference data for work placement, since the guideline expressly stated that the administration should make it a principle to match new graduates with job offers from companies posting good retention records. It was only natural for the administrative authorities to think highly of work placement, with an aim to improve both the quality and quantity of jobs with which new graduates were matched under the "strong adjustment system".

Viewed from the angle of the young workers themselves, however, a different appraisal of the system starts to emerge. A sellers' market logically broadens job-seekers' occupational choices as long as the free market mechanism is in play. Nonetheless, what actually happened in the graduate labor market in the 1960s was the exact opposite of this theoretical assumption. While increasing numbers of job-seeking students joined the system, the number of placements per applicant dropped sharply despite a sharp rise in the number of job offers. The drastic transition to a labor shortage economy did not broaden individuals' occupational horizons, but rather strengthened the "institutions".

Furthermore, this intensified "protection and control" system had a negative impact on young workers' career development. While new jobs were increasingly created in the rapidly expanding economy, PESOs were very reluctant to help young workers change jobs and pursue a career as independent individuals. As shown by a former official's testimony, it was regarded as a good thing to stay put and bad to change jobs unquestioningly, with the old-fashioned occupational philosophy of "perseverance will win in the end" stubbornly resisting and surviving in the rapidly changing environment. There is no denying that the system's endemic disadvantages grew all the more conspicuous in the 1960s, when the Japanese economy attained full employment and the market situation was most advantageous to job-seekers.

\section{Conclusion}

This paper explored in detail the development of labor market institutions for junior high school graduates in postwar Japan. The chief points illustrated can be summarized as follows:

First, the issue of junior placement guidelines in 1925 marked the beginning of graduate placement work by public institutions. The guidelines called for labor exchanges to provide a special service for primarily 14-year-old graduates from upper elementary schools. Labor exchanges were instructed to work in cooperation with elementary schools to find "suitable jobs" for individual boys and girls based on "scientific" assessments of their skills.

Second, such initiatives developed, under the wartime planned economy, into the system in which the state allocated the manpower of new elementary school graduates according to the necessity of the nation. The historical and institutional legacies of the wartime planned economy were bequeathed, despite postwar democracy, to the job placement service for new junior high school graduates provided by postwar employment security administration.

Third, this job placement system organized and adjusted, during the high-speed economic growth, the enormous flux of the workforce consisting of new junior high school graduates moving from countryside to big cities. It was not the "invisible hand" 
of the market, but these visible institutional arrangements that smoothed the transition in the period of industrial and occupational structural changes, thus giving birth to contemporary Japanese society.

Fourth, these institutions evolved with their aims and roles varied with fluctuations in the labor market's ratio of supply and demand. In the late 1940s and the 1950s when Japanese economy was under pressure of a large labor supply, the most important goal of placement work was to secure enough job openings for new graduates. In the 1960s when the market situation changed drastically from a buyer's market to a seller's market, this goal shifted and the administration took affirmative steps to regulate the free play of employers, with an aim to improve the quality as well as quantity of jobs with which new graduates were matched under the "strong adjustment system".

While graduate placement system underwent dynamic evolution in four stages from 1925 to 1970, a theory underlying the system was most likely to remain unchanged in principle. At its very start, Misawa clearly stated that, "Junior workers nowadays are ignorant of the world of work and occupations, and know very little about their own vocational skills ... The government therefore needs to provide them with suitable jobs, to regulate and oversee their job-seeking activities, and in certain cases, to guide them directly into specific occupations".

This Misawa's statement gets to the heart of the matter: The system based on the principle of "protection and control" was obliging as well as interfering to the individuals involved. And that makes it most difficult to appraise the roles of placement work system viewed from the standpoint of young workers themselves, with the advantages intimately interwoven with the disadvantages. The arguments in the last section, however, show that this delicate balance between advantages and disadvantages are also changeable. Since the 1970s, especially 1990s, Japanese labor market institutions have been undergoing further evolution, and the above findings would be, it seems, most suggestive for designing the new institutional arrangements in the twenty-first century.

\section{Endnotes}

${ }^{1}$ Ujihara, Shōjirō and Takanashi, Akira, Nihon Rōdō Shijō Bunseki (Jō) (An analysis of the Japanese labor market, volume 1), (Tokyo: University of Tokyo Press, 1970).

${ }^{2}$ The analysis in this section and the following two sections is based primarily on Sugayama,Shinji, Shü-sha Shakai no Tanjō (The birth of shü-sha society), (Nagoya: Nagoya Daigaku Shuppankai, 2011), chap. 5, pp. 338-443. Revisions have been made.

${ }^{3}$ Tokyo Shokugyō Shōkai Jimukyoku, Shōnen Shokugyō Shōkai Shisetsu Yōryō (An outline of junior placement programs), 1927.

${ }^{4}$ Frederick A. King, "Junior Workers", in Harrison, M. Shelby et al, Public Employment Offices, (New York: Russel Sage Foundation, 1924), pp. 564-568.

${ }^{5}$ Tokyo Shokugyō Shōkai Jimukyoku, Shōnen Shokugyō Shōkai.

${ }^{6}$ Tokyo Shokugyō Shōkai Jimukyoku, Shōnen Shokugyō Shidō to Shōkai (Vocational guidance and junior work placement), 1927.

${ }^{7}$ Kōseishō, Shōgakkō Jidō Shūshoku ni kansuru Shiryō (Data on Junior Work placement), 1938. 
${ }^{8}$ Kōseishō Shokugyōbu, "Shōgakkō Sotsugyōsha no Shokugyō Shidō narabi ni Shokugyō Shōkai ni tsuite (On vocational guidance and junior work placement)," Shokugyō Jihō, Vol. 6, No. 7, 1938, pp. 15-19, 98-108.

${ }^{9}$ Kōseishō Shokugyōbu, Shōwa 14nen Shōgakkō Sotsugyōsha no Shokugyō Shōkai Kankei Tsūchō (Collections of junior work placement guidelines issued in 1939), 1939.

${ }^{10}$ Negishi, Kōhei, "Rōmu Chōseika ni okeru Shinki Gakkō Sotsugyōsha no Haichi to Shūshoku" (Placement and vocational guidance of new school graduates), Shokugyō Shidō, Vol. 15, No.-6, 1941, pp. 410-419

${ }^{11}$ Kudō, Seiji, Shokugyō Antei Hō Kaisetsu (Commentary on the employment security law), (Tokyo: Tairyūsha, 1948).

${ }^{12}$ Rōdōshō, Shokugyō Antei Gyōsei Tebiki (Employment security administration manuals), 1948.

${ }^{13}$ Tōyō Bōseki Kabushiki Kaisha, Tōyō Bō 100 Nenshi (Jō) (A hundred years of Toyo Textile Corporation, volume 1), (Osaka: Tōyō Bōseki, 1986).

${ }^{14}$ Rōdōshō, Shokugyō Antei Gyōsei Tebiki (Employment security administration manuals), 1949.

${ }^{15}$ For example, see J. Tomiyama, "Gakkō Sotsugyōsha no Shūshoku Kakuho ni Nozomu (Towards enough job openings for new graduates)," Shokugyō Antei Kōhō, February 1953. pp. 6-8

16“'Chūgaku Kōkō Sotugyōsha no Kyūjin Kyūshoku Jōhō; Niigata, Kanagawa, Aichi, Hyōgo, Fukuoka, and Kagoshima (Labor market situation for junior and senior high school graduates: Niigata, Kanagawa, Aichi, Hyōgo, Fukuoka, Kagoshima)," Shokugyō Kenkyū, February 1956, pp. 17-34.

${ }^{17}$ This number is apparently an error, since 1,742 people would be correct.

${ }^{18}$ Mizusawa, Isamu, "Gakusotsu no Kyūjin Nan to Sono Taisaku (Labor shortage of school graduates and its countermeasures)," Shokugyō Antei Kōhō, April 1961, pp. 27-29.

${ }^{19}$ The 1960 guideline is included in "Honnendo Chūsotusha Jukyū Chōsei Yōryō to Sono Mondaiten (Outline of the adjustment policy for the supply and demand of junior high school graduates this year and the points at issue )," Bōseki Rōmu Geppō , No.96, 1960, pp.4-13.

${ }^{20}$ Rōdōshō Shokugyō Anteikyoku, Jūgyōin Saiyō to Gakusotshusha Boshū no Tebiki (High school graduate recruitment manuals), (Tokyo: Rōdō Hōrei Kyōkai, 1964).

21"42 nendo Chūsotsusha Shokugyō Shōkai ni tsuite (Junior high school graduate work placement in 1967)," Bōseki Rōmu Geppō , No.187, 1967, pp. 15-29.

${ }^{22}$ Mizusawa (Employment Security Section), "Shinki Gakkō Sotsugyōsha no Nenkan Keikaku to Jukyū Chōsei (Annual schedule and adjustment of high school graduate supply and demand)," Shokugyō Antei Kōhō, July 1961, pp. 15-18 and August 1961, pp. 28-31.

${ }^{23}$ Rōdōshō, Rōdō Shijō Nenpō (Annual Labor Market Report), each year.

${ }^{24}$ The discussion owes a great deal to Ishida, Hiroshi, "Gakkō Shokuan ga Kaizai-shita Job Matching no Hyōka (An appraisal of the job-matching system in which schools and PESOs intermediated)," in Kariya, Takehiko, Sugayama, Shinji, and Ishida, Hiroshi eds., Gakkō Shokuan to Rōdō Shijō (Schools, public employment offices, and the labor market in postwar Japan), (Tokyo: University of Tokyo Press, 2000), pp. 274-285.

${ }^{25}$ An interview with Tetsuya Jō held on October 13, 1995 at Tohoku Gakuin University. Mr. Jō joined the Ministry of Labor in 1961, and was in charge of work placement for junior high school graduates in Miyagi prefecture between 1962 and 1964. 
${ }^{26}$ Ibid.

${ }^{27}$ The Asahi Shimbun (The Asahi newspaper), December 25, 1966. The Asahi chose seven junior high schools at its will and made a complete investigation on their graduates in the class of 1963 who had found employment outside their home prefecture. The survey subjects were 417 persons and included those who found employment via personal connections.

${ }^{28}$ Tokyo Daigaku Kyōiku Gakubu, Kanagawa-ken ni okeru Ryūnyū Seishōnen no Tekiō to Teichaku ni kansuru Chōsa Kenkyu (A research study into the adaptation and retention of the influx of young workers into Kanagawa prefecture), 1967, p.57. The research subjects were 1,435 male factory workers aged 16-24 employed by small and medium-sized manufacturers located in Kanagawa prefecture. The breakdown by length of service is $66 \%$ for those with $1-3$ years' service, $28 \%$ for those with $4-6$ years' service, $5 \%$ for those with 7-9 years' service, and 1\% for D.K.

${ }^{29}$ Tokyoto Rōdōkyoku, Shinki Gakkō Sotugyōsha Shugyō Jittai Chōsa Hokoku, (A research report on actual working conditions among high school graduates), 1965, pp.328-329. The survey subjects were 1,415 male workers who graduated from junior high schools on March 1964, and were employed as of September 30, 1964 by establishments with more than five regular employees in the manufacturing industry, the wholesale and retail industry and the service industry.

${ }^{30} \mathrm{My}$ opinion differs from Kazutoshi Kase in this respect. In his work on "shūdan shūshoku" with a reputation, Kase rates the role of the job placement system as very small, writing:"There is no denying it didn't pay for students to follow guidance given by junior high schools and PESOs in this system. It makes perfect sense that many students sought better jobs by making use of personal connections." Quoted from K. Kase, "Shūdan Shūshoku" no Jidai (The age of "shūdan shūshoku"), (Tokyo: Aoki Shoten, 1997), p.141.

${ }^{31}$ Ishida, op. cit., pp. 279-284. However, Ishida also points out the possibility that there was a disparity in accessibility to work placement based on the place job-seeking students came from, since PESOs were not necessarily evenly distributed nationwide, with many more in densely-populated urban areas and far fewer in rural areas with poor transportation facilities.

${ }^{32}$ Rōdōshō Shokugyō Anteikyoku, Jūgyōin Saiyō.

Abbreviation

PESOs: Public Employment Security Offices

Acknowledgments

I would like to thank Prof. Bernard Thomann for his helpful remarks on an earlier draft of this paper.

Funding

Not applicable.

Availability of data and materials

Not applicable.

Open access

This article is distributed under the terms of the Creative Commons Attribution 4.0 International License (http:// creativecommons.org/licenses/by/4.0/), which permits unrestricted use, distribution, and reproduction in any medium, provided you give appropriate credit to the original author(s) and the source, provide a link to the Creative Commons license, and indicate if changes were made. 
Competing interests

The author declares that he has no competing interests.

\section{Publisher's Note}

Springer Nature remains neutral with regard to jurisdictional claims in published maps and institutional affiliations.

Received: 5 September 2018 Accepted: 31 January 2019

Published online: 15 March 2019

\section{References}

Ishida, Hiroshi. 2000. Gakkō Shokuan ga Kaizai-shita Job Matching no Hyōka (An appraisal of the job-matching system in which schools and PESOs intermediated). In Gakkö Shokuan to Rödō Shijō (Schools, public employment offices, and the labor market in postwar Japan), ed. Takehiko Kariya, Shinji Sugayama, and Hiroshi Ishida. Tokyo: University of Tokyo Press. Kase, Kazutoshi. 1997. "Shüdan Shüshoku" no Jidai (The age of "shüdan shüshoku"). Tokyo: Aoki Shoten.

King, Frederick A. 1924. Junior Workers. In Public Employment Offices, ed. M. Shelby Harrison et al. New York: Russel Sage Foundation.

Kōseishō, 1938, Shōgakkō Jidō Shūshoku ni kansuru Shiryō (Data on Junior Work placement).

Kōseishō Shokugyōbu, 1939, Shōwa 14nen Shōgakkō Sotsugyōsha no Shokugyō Shōkai Kankei Tsūchō (Collections of junior work placement guidelines issued in 1939).

Kudō, Seiji. 1948. Shokugyō Antei Hō Kaisetsu (Commentary on the employment security law). Tokyo: Tairyūsha.

Rōdōshō, 1948, Shokugyō Antei Gyōsei Tebiki (Employment security administration manuals).

Rōdōshō, 1949, Shokugyō Antei Gyōsei Tebiki (Employment security administration manuals).

Rōdōshō Shokugyō Anteikyoku. 1964. Jūgyōin Saiyō to Gakusotshusha Boshū no Tebiki (High school graduate recruitment manuals). Tokyo: Rōdō Hōrei Kyōkai.

Sugayama, Shinji. 2011. Shü-sha Shakai no Tanjō (The birth of shü-sha society). Nagoya: Nagoya Daigaku Shuppankai.

Tokyo Daigaku Kyōiku Gakubu, 1967, Kanagawa-ken ni okeru Ryūnyū Seishōnen no Tekiō to Teichaku ni kansuru Chōsa Kenkyu (A research study into the adaptation and retention of the influx of young workers into Kanagawa prefecture).

Tokyo Shokugyō Shōkai Jimukyoku, 1927a, Shōnen Shokugyō Shōkai Shisetsu Yöryō (An outline of junior placement programs).

Tokyo Shokugyō Shōkai Jimukyoku, 1927b, Shōnen Shokugyō Shidō to Shōkai (Vocational guidance and junior work placement).

Tokyoto Rōdōkyoku, 1965, Shinki Gakkō Sotugyōsha Shugyō Jittai Chōsa Hokoku, (A research report on actual working conditions among high school graduates).

Tōyō Bōseki Kabushiki Kaisha. 1986. Tōyō Bō 100 Nenshi (Jō) (A hundred years of Toyo Textile Corporation, volume 1). Osaka: Tōyō Bōseki.

Ujihara, Shōjirō, and Akira Takanashi. 1970. Nihon Rōdō Shijō Bunseki (Jō) (An analysis of the Japanese labor market, volume 1). Tokyo: University of Tokyo Press.

\section{Submit your manuscript to a SpringerOpen ${ }^{\circ}$ journal and benefit from:}

- Convenient online submission

- Rigorous peer review

- Open access: articles freely available online

- High visibility within the field

- Retaining the copyright to your article

Submit your next manuscript at $\boldsymbol{\nabla}$ springeropen.com 